\title{
Mathematical Modelling of Thin Layer Drying Kinetics of Biodegradable Pellets
}

\author{
Kulsum Jan, Riar CS and Saxena DC*
}

Department of Food Engineering and Technology, Sant Longowal Institute of Engineering \& Technology, Longowal - 148 106, Punjab, India

\begin{abstract}
The deoiled rice bran, industrial waste (paddy husk, potato peels and banana peels) and plasticizers were added to develop pellets after extrusion for their further use in preparing molds (pots) for horticultural use. Pellets were prepared by extrusion technology using glycerol and cashew nut shell liquid as plasticizers and were dried in a chamber with constant air circulation $(1.5 \mathrm{~m} / \mathrm{sec})$. Drying kinetics of pellets made from different formulations was studied at different temperatures $\left(60,70\right.$ and $\left.80^{\circ} \mathrm{C}\right)$. In declining rate period, moisture transfer from pellets was described by applying 12 different mathematical models, and the corresponding rate constants $(\mathrm{k})$ were calculated. The models in each case were finally selected to explain the drying behaviour based on Chi-square, RMSE and R2. Results indicated that removal of moisture from these pellets was rapid in initial hours and increased with increase in temperature as well. The effect of temperature on rate constant $(k)$ was interpreted according to Arrhenius law. Drying rate and hence, $\mathrm{k}$ values were found to be significantly affected by temperature. The energy value increased upon increasing the plasticizer concentration (CNSL and Glycerol) in the formulation. Also, the energy required in the drying of pellets with CNSL as a plasticizer was higher as compared to those with the glycerol.
\end{abstract}

Keywords: Deoiled rice bran; Paddy husk; Potato peels; Banana peels; Cashew nut shell liquid

\section{Introduction}

Nursery owners or growers use pots and cell trays of different materials, sizes, shapes, and colours to suit crop species, growing methods, and marketing strategies [1]. At nurseries and greenhouses, seeds, bulbs, and young plants are planted in cell trays or pots containing growing substrate to start the growth under uniform cultivation conditions. However, one of the limitations of impermeable and rigid containers is that roots tend to encircle the outer perimeter of the pot which results in reduced plant growth, health, and survival once transplanted [2]. Most of the containers used for transplanting are made of non-renewable oil-based raw materials such as polystyrene, polyethylene and polypropylene with suitable mechanical properties, chemical and microbial degradation resistance as well as durability. But at the same time disposal and recycling process of post-use plastic pots determine their uncontrolled combustion with the subsequent emission of toxic substances both into the atmosphere and into the soil. Hence, a valid alternative to the employment of petroleum based thermoplastic pots may be represented by the use of biodegradable pots [1-5]. Once buried, the biodegradable pots are subjected to biodegradation process, being transformed in biomass and inorganic products. Now, the attention is being focussed on the development of novel biodegradable and cost-competitive pots or multiple nurseries. These pots are biocomposites whose continuous phase is characterized by biopolymers coming from renewable and available origin, such as polysaccharides [6,7] and whose solid phase, dispersed within the polymeric matrix, is represented by natural fillers and fibres coming from wastes of agro-food and textile processing industries [8]. There is a substantial interest in replacing some or all of the synthetic plastics by biodegradable polymers in several applications. Industrial production of pellets by extrusion process for manufacture of biodegradable products is relatively new and therefore the effectiveness of the availability of pellets rely upon understanding the storage stability of these pellets. A novel kind of low cost, biodegradable and medium water-resistant composite from corn protein was developed by $\mathrm{Wu}$ et al. [4]. wherein glycerol-plasticized pots showed good biodegradability and promising water resistance [8].
The thermal energy generated by viscous dissipation during extrusion combines with the shearing effect. Several studies have reported chemical changes during extrusion cooking and related them to product functional qualities e.g. expansion volume, water solubility and color $[4,9]$.

In order to study the consequences of the drying on the pellets it's necessary to possess a deep data of the mass transfer parameters and also the drying kinetics. The mathematical models have been established to be helpful in the new design and/or improvement of drying systems and analysis of mass transfer phenomena concerned throughout drying [10]. The optimal control of a drying process is thus critical and needs complete information regarding the drying behaviour of materials. Drying kinetics may be described using the transport properties such as thermal conductivity, thermal diffusivity, moisture diffusivity as well as interface heat and mass transfer coefficients [11].

Previous research is available on the dilatometry studies of phosphotungstic acid pellets during hydration and dehydration processes [12]. Bassene et al. [13] performed thin layer drying kinetics of pellets prepared from millet flour at different drying air temperatures and found that modified Henderson and Pabis was the best model to describe the behaviour of pellets from millet flour.

Since literature is scanty on the drying behavior/ characteristics of pellets used for development of biodegradable products, the present study was undertaken to describe the drying mechanism of pellets

*Corresponding author: Saxena DC, Professor and Head, Department of Food Engineering and Technology, Sant Longowal Institute of Engineering \& Technology, Longowal - 148 106, Punjab, India, Tel: +91-98-156-088-59; E-mail:dcsaxena@yahoo.com

Received July 16, 2014; Accepted August 30, 2014; Published September 03 2014

Citation: Jan K, Riar CS, Saxena DC (2014) Mathematical Modelling of Thin Layer Drying Kinetics of Biodegradable Pellets. J Food Process Technol 5: 370 doi:10.4172/2157-7110.1000370

Copyright: @ 2014 Jan K, et al. This is an open-access article distributed under the terms of the Creative Commons Attribution License, which permits unrestricted use, distribution, and reproduction in any medium, provided the original author and source are credited. 
developed from different industrial byproducts, wastes and plasticizers at different drying temperatures.

The objectives of the present study are:

- $\quad$ To study the applicability of several mathematical models selected from literature to the drying of biodegradable pellets of different formulations

- To fit the drying data into the most suitable models by appropriate regression analysis in order to investigate the best model for describing the drying characteristics of the pellets.

\section{Materials and Methods}

\section{Procurement of raw material}

Deoiled rice bran used for the present study was kindly donated by M/s. AP Solvex Ltd., Dhuri (Punjab, India) which contain high level of protein helpful for binding of material to other ingredients. Glycerol was used as a reference plasticizer in this study was of analytical grade (M/s. Merck Specialities Pvt. Ltd., Mumbai, India). Other plasticizer used in this study was cashew nut shell liquid kindly donated by $\mathrm{M} / \mathrm{s}$. Allen Petrochemicals Pvt Lt., Meerut (India). Paddy husk was also provided from M/s. AP Solvex Ltd., Dhuri. Banana peels and potato peels were procured locally from local juice vendors and Hostel Mess as well as Canteen, respectively.

\section{Sample preparation}

Preparation of banana and potato peel powder: Paddy husk was ground in a Laboratory grinding mill (M/s. Philips India Limited, Kolkata, India) and passed through 60 mesh screen to obtain fine powder. Banana peels and potato peels were washed with water impregnated with citric acid (1\%) and $\mathrm{KMnSO}_{4}(0.5 \%)$ to check the enzymatic browning. The peels were cut into transverse slices of about $2 \mathrm{~mm}$ thickness and dried in tray drier at $65^{\circ} \mathrm{C}$ overnight. The dried peels were ground in a Laboratory grinding mill as mentioned above and passed through 60 mesh screen to obtain powders. All powders were stored in airtight HDPE plastic packs for further use.

\section{Extrusion process for the preparation of pellets}

In the blend preparation, ingredients like deoiled rice bran, paddy husk powder, potato peel powder, banana peel powder, cashew nut shell liquid and glycerol were used at levels shown in Table 1 . The moisture was adjusted by sprinkling the distilled water on all the dry ingredients. All the ingredients were weighed and then mixed in a Hobart mixer (M/s. Continental Equipment India Pvt. Ltd, Delhi, India) for $20 \mathrm{~min}$ at $328 \mathrm{rpm}$ using sigmoid shape blade. This mixture was then passed through an 80 mesh sieve to eliminate the lumps formed due to addition of moisture. After mixing, samples were stored in polyethylene bags at room temperature for 24h. Extrusion was performed using a co-rotating twin-screw extruder (M/s. Basic Technology Pvt. Ltd., Kolkata, India). The twin screw extruder was kept running for suitable period of time to stabilize the set temperatures and samples were then fed in to feed hopper at the feed rate of $4 \mathrm{~kg} / \mathrm{h}$ for easy and non-choking operation. Screw speed was set at $125 \mathrm{rpm}$ and the suitable quantity of water was added to makeup the moisture content to $10 \%$. The horizontal split design of the extruder allowed the collection of samples inside the extruder channel with a 'dead-stop' run. Samples were taken along the extruder channel and made into pellets using suitable die and high speed cutter. The pellets had on average about $7 \%$ moisture content. The preliminary experiments carried out to study the moisture isotherms (unpublished) showed that the pellets being hygroscopic absorbed moisture to about $30 \%$ in different storage

\begin{tabular}{|c|c|c|c|}
\hline S. No. & Model Name & Model Equation & References \\
\hline 1 & Newton & $M R=\exp ^{(-k t)}$ & O'Callaghan et al. [18] \\
\hline 2 & Page & $M R=\exp ^{(-k t n)}$ & Doymaz,[19,20] \\
\hline 3 & Thompson & $\begin{array}{l}t=a \ln (M R)+b \\
{[\ln (M R)]^{2}}\end{array}$ & Jompob et al. [15] \\
\hline 4 & Henderson and Pabis & $M R=a \exp ^{(-k t)}$ & Ibrahim et al. [21,22] \\
\hline 5 & $\begin{array}{l}\text { Modified Henderson } \\
\text { and Pabis }\end{array}$ & $\begin{array}{l}\mathrm{MR}=a \exp ^{(-k t)}+b \exp ^{(-} \\
g t)+c \exp ^{(-h t)}\end{array}$ & Akpinar [23] \\
\hline 6 & Logarithmic & $M R=a \exp ^{(-k t)}+c$ & $\begin{array}{l}\text { Balasubramanian et al. } \\
\text { [24] }\end{array}$ \\
\hline 7 & Two-term exponential & $\begin{array}{l}M R=a \exp ^{(-k t)}+(1-a) \\
\exp ^{(-k a t)}\end{array}$ & Akpinar [23] \\
\hline 8 & Two-term & $\begin{array}{l}M R=a \exp ^{(-k t)}+b \\
\exp ^{(-g t)}\end{array}$ & Ertekin et al. [25] \\
\hline 9 & Verma & $\begin{array}{l}M R=a \exp ^{(-k t)}+(1-a) \\
\exp ^{(-g t)}\end{array}$ & Yaldiz et al. [26] \\
\hline 10 & Midilli & $\mathrm{MR}=\mathrm{a} \exp ^{(-\mathrm{ktn})}+\mathrm{bt}$ & Midilli et al. [27] \\
\hline 11 & Diffusion approach & $\begin{array}{l}M R=a \exp ^{(-k t)}+(1-a) \\
\exp ^{(-k b t)}\end{array}$ & Cihan et al. [28] \\
\hline 12 & Wang and Singh & $M R=a t^{2}+b t+1$ & Mohapatra et al. [29] \\
\hline
\end{tabular}

conditions. This required drying of pellets to suitable moisture content before using injection moulding to prepare pots.

\section{Drying kinetics of pellets}

The drying experiments carried out in a tray dryer (M/s. Balaji Enterprises, Saharanpur, India) at selected three air drying temperatures $\left(60,70\right.$ and $\left.80^{\circ} \mathrm{C}\right)$ to study the drying characteristics of the pellets. The drying cabinet was equipped with an electrical heater, a fan, and temperature indicators. Air velocity was set at $1.5 \mathrm{~m} / \mathrm{s}$. When the dryer reached steady state conditions (i.e. when desired temperature was reached) the pellets were spread onto the trays. Moisture loss was recorded at every 15 min intervals during drying. Drying was continued until the moisture content of the sample reached to the equilibrium moisture content. The drying was continued till weight became constant. The experiments were conducted in duplicates.

\section{Drying kinetics model}

Various types of mathematical models have been used to describe drying of pellets, ranging from theoretical models based on classical diffusion theory and simplified forms of these to purely empirical models as shown in Table 1 .

\section{Statistical evaluation}

The results obtained were statistically evaluated using Excel worksheet of MS office version 2010 (MS Office) and Statistica-log software package version 7 (StatSoft Inc., OK, USA). The regression analysis was performed using the STATISTICA computer program. Nonlinear regression, which used to evaluate goodness of fit of the mathematical models to the experimental data are coefficient of determination $\left(\mathrm{R}^{2}\right)$, the reduced chi-square $\left(\chi^{2}\right)$ and \% Root Mean Square Error (RMSE) was used for data analysis and calculated as below:

$$
\begin{aligned}
& R M S E=\sum_{i=1}^{N} \sqrt{\frac{\left(M R_{\text {Experimental Value }}-M R_{\text {Predicted Value }}\right)^{2}}{N}} \\
& \chi^{2}=\sum_{i=1}^{N} \frac{\left(M R_{\text {Experimental Value }}-M R_{\text {Predicted Value }}\right)^{2}}{(N-n)}
\end{aligned}
$$


Citation: Jan K, Riar CS, Saxena DC (2014) Mathematical Modelling of Thin Layer Drying Kinetics of Biodegradable Pellets. J Food Process Technol 5: 370. doi:10.4172/2157-7110.1000370

Page 3 of 5

\section{Results and Discussion}

\section{Drying rate}

The variation of moisture content with drying time is obtained for each sample made from different formulations. From these results, drying rates were calculated and then plotted against time. Plots of MR against drying time showed a linear relationship as shown in representative graphs in Figure 1, which indicates that the entire drying curve can be represented approximately by a diffusion model. In all the cases, the drying rate decreased continuously throughout the drying period. The drying took place in the falling rate period. Similar type of observation was reported by Singh et al. [14] wherein the drying rate of sweet potato slices decreased continuously throughout the drying period.

\section{Selection of drying models}

The convective drying of biological materials in the falling rate period is diffusion controlled process and may be represented by Fick's second law of diffusion. Different types of mathematical models have been used to describe drying of foodstuffs, ranging from theoretical models based on classical diffusion theory and simplified forms of these to purely empirical models [15]. The drying data were converted to moisture ratios which were then fitted to twelve drying models at

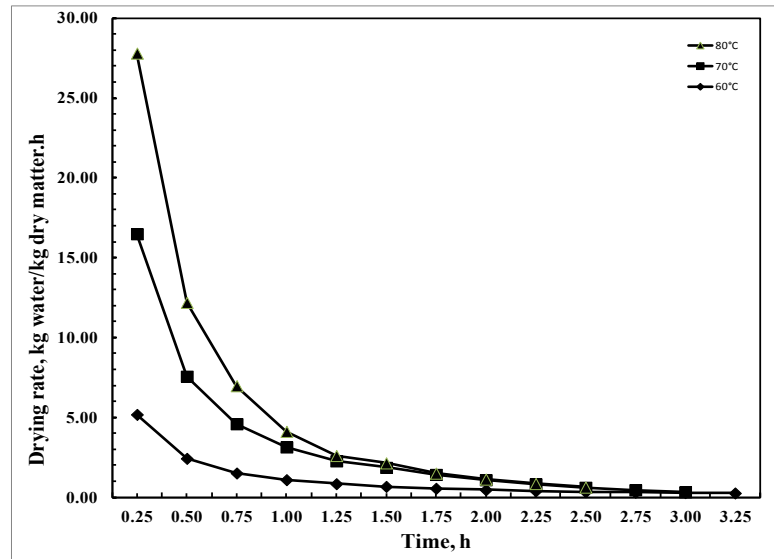

Figure 1: Drying rate curves for pellets made from deoiled rice bran $(75 \mathrm{~g})$ potato peel powder $(75 \mathrm{~g})$, CNSL $(9 \mathrm{ml})$ at different temperatures.

\begin{tabular}{|c|c|c|c|c|c|c|c|c|c|}
\hline S.No. & \multicolumn{2}{|c|}{ Raw material (g) } & Plasticizer(ml) & Code & Models & Parameters & $x^{2}$ & RMSE & $\mathbf{R}^{2}$ \\
\hline 1 & \multirow{12}{*}{ 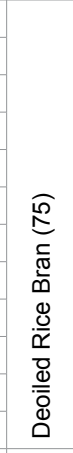 } & \multirow{3}{*}{$\begin{array}{l}\text { Paddy } \\
\text { Husk (75) }\end{array}$} & Gly (9) & A160 & Midilli & n: 1.436 ; a: 0.997 ; b: -0.005 ; k: 0.903 & 0.004 & 0.001 & 0.999 \\
\hline 2 & & & Gly (15) & A260 & Logarithmic & a: 1.449 ; c: -0.528 ; k: 0.309 & 0.028 & 0.036 & 0.983 \\
\hline 3 & & & Gly (21) & A360 & Verma & a: 252.609 ; g: 0.616 ; k: 0.617 & 0.016 & 0.030 & 0.990 \\
\hline 4 & & \multirow{3}{*}{$\begin{array}{l}\text { Potato } \\
\text { Peel (75) }\end{array}$} & CNSL (9) & B160 & Midilli & n: 0.735 ; a: 1.002 ; b: -0.108 ; k: 0.615 & 0.004 & 0.011 & 0.998 \\
\hline 5 & & & CNSL (15) & B260 & Midilli & n: 1.513 ; a: 0.989 ; b: -0.061 ; k: 0.296 & 0.003 & 0.020 & 0.997 \\
\hline 6 & & & CNSL (21) & B360 & Midilli & n: 0.210 ; a: 18.764 ; b: -0.077 ; k: 3.354 & 0.010 & 0.014 & 0.997 \\
\hline 7 & & \multirow{3}{*}{$\begin{array}{l}\text { Banana } \\
\text { Peel (75) }\end{array}$} & CNSL (9) & C160 & Diffusion & a: $1.587 ;$ b: 0.999 ; k: 1.435 & 0.709 & 0.060 & 0.969 \\
\hline 8 & & & CNSL (15) & C260 & Midilli & n: 0.220 ; a: 1.000 ; b: -0.185 ; k: 0.519 & 0.002 & 0.007 & 0.999 \\
\hline 9 & & & CNSL (21) & C360 & Midilli & n: 0.321 ; a: 0.999 ; b: -0.152 ; k: 0.657 & 0.011 & 0.013 & 0.998 \\
\hline 10 & & \multirow{3}{*}{$\begin{array}{l}\text { Paddy } \\
\text { Husk (75) }\end{array}$} & CNSL (9) & D160 & Logarithmic & a: $0.778 ; c: .035 ; \mathrm{k}: 0.53$ & 0.267 & 0.082 & 0.868 \\
\hline 11 & & & CNSL (15) & D260 & Page & $\mathrm{n}: 1.535 ; \mathrm{k}: 0.337$ & 0.111 & 0.044 & 0.979 \\
\hline 12 & & & CNSL (21) & D360 & Midilli & n: 0.639 ; a: 1.005 ; b: -0.030 ; k: 0.117 & 0.008 & 0.014 & 0.997 \\
\hline 1 & \multirow{12}{*}{ 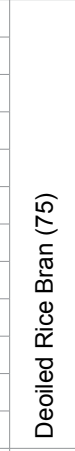 } & \multirow{3}{*}{$\begin{array}{l}\text { Paddy } \\
\text { Husk (75) }\end{array}$} & Gly (9) & A170 & Midilli & n: 1.114 ; a: 1.000 ; b: -0.090 ; k: 0.989 & 0.008 & 0.014 & 0.997 \\
\hline 2 & & & Gly (15) & A270 & Logarithmic & a: 2.013 ; c: -1.041 ; k: 0.406 & 0.004 & 0.017 & 0.995 \\
\hline 3 & & & Gly (21) & A370 & Modified Henderson & g:0.660; c: $0.443 ;$ h: 0.660; a: 0.100;b:0.444; k:0.7305 & 0.100 & 0.048 & 0.968 \\
\hline 4 & & \multirow{3}{*}{$\begin{array}{l}\text { Potato } \\
\text { Peel (75) }\end{array}$} & CNSL (9) & B170 & Diffusion & a: 1.000 ; b: -3.879 ; k: 0.898 & 0.013 & 0.024 & 0.993 \\
\hline 5 & & & CNSL (15) & B270 & Logarithmic & a: $2.010 ; \mathrm{c}:-1.092$; k: 0.363 & 0.038 & 0.041 & 0.975 \\
\hline 6 & & & CNSL (21) & B370 & Logarithmic & a: 8.806 ; c: -7.820 ; k: 1.989 & 0.019 & 0.028 & 0.990 \\
\hline 7 & & \multirow{3}{*}{$\begin{array}{l}\text { Banana } \\
\text { Peel (75) }\end{array}$} & CNSL (9) & C170 & Modified Henderson & g: 1.929; c:-186.91; h:2.097; a:89.824;b:98.09; k:1.251 & 0.032 & 0.028 & 0.988 \\
\hline 8 & & & CNSL (15) & $\mathrm{C} 270$ & Logarithmic & a: 1.327 ; c: -0.377 ; k: 0.665 & 0.019 & 0.033 & 0.985 \\
\hline 9 & & & CNSL (21) & C370 & Logarithmic & a: 1.690 ; c: -0.771 ; k: 0.415 & 0.041 & 0.053 & 0.959 \\
\hline 10 & & \multirow{3}{*}{$\begin{array}{l}\text { Paddy } \\
\text { Husk (75) }\end{array}$} & CNSL (9) & D170 & Logarithmic & a: 10.338 ; c: -9.332 ; k: 2.272 & 0.006 & 0.003 & 0.999 \\
\hline 11 & & & CNSL (15) & D270 & Diffusion & a: 0.562 ; b: 25.597 ; k: 0.807 & 2.880 & 0.378 & 0.861 \\
\hline 12 & & & CNSL (21) & D370 & Midilli & n: $0.711 ; a: 0.999 ; b:-0.065 ; k: 0.516$ & 0.016 & 0.020 & 0.989 \\
\hline 1 & \multirow{12}{*}{ 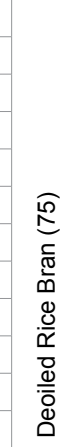 } & \multirow{3}{*}{$\begin{array}{l}\text { Paddy } \\
\text { Husk (75) }\end{array}$} & Gly (9) & A180 & Diffusion & a: 1.000 ; b: $-5.849 ; \mathrm{k}: 1.225$ & 0.028 & 0.023 & 0.993 \\
\hline 2 & & & Gly (15) & A280 & Midilli & n: 0.450 ; a: 0.999 ; b: -0.188 ; k: 0.496 & 0.019 & 0.028 & 0.989 \\
\hline 3 & & & Gly (21) & A380 & Midilli & n: -0.079 ; a: $-0.079 ; b:-0.079 ; k: 1.210$ & 0.009 & 0.019 & 0.996 \\
\hline 4 & & \multirow{3}{*}{$\begin{array}{l}\text { Potato } \\
\text { Peel (75) }\end{array}$} & CNSL (9) & B180 & Midilli & n: 1.692 ; a: 0.980 ; b: 0.016 ; k: 1.163 & 0.026 & 0.0299 & 0.991 \\
\hline 5 & & & CNSL (15) & B280 & Modified Henderson & g:1.160; c:0.491; h:1.160; a: 0.091; b:0.491; k:0.689 & 0.017 & 0.028 & 0.990 \\
\hline 6 & & & CNSL (21) & B380 & Page & $\mathrm{n}: 1.281 ; \mathrm{k}: 1.312$ & 0.038 & 0.043 & 0.983 \\
\hline 7 & & \multirow{3}{*}{$\begin{array}{l}\text { Banana } \\
\text { Peel (75) }\end{array}$} & CNSL (9) & C180 & Midilli & n: 0.373 ; a: 0.999 ; b: -0.17 ; k: 0.987 & 0.020 & 0.026 & 0.991 \\
\hline 8 & & & CNSL (15) & C280 & Modified Henderson & g:2.768; c:-152.73; h:2.519; a:81.280; b:72.458;k:0.894 & 0.010 & 0.014 & 0.998 \\
\hline 9 & & & CNSL (21) & C380 & Verma & a: $4.076 ; \mathrm{g}: 0.220 ; \mathrm{k}: 0.345$ & 0.010 & 0.023 & 0.995 \\
\hline 10 & & \multirow{3}{*}{$\begin{array}{l}\text { Paddy } \\
\text { Husk (75) }\end{array}$} & CNSL (9) & D180 & Midilli & g:2.485; c:-382.10; h:2.672; a:183.85; b:199.25;k:2.272 & 0.063 & 0.048 & 0.975 \\
\hline 11 & & & CNSL (15) & D280 & Modified Henderson & g:2.10; c:0.222; h:35.59; a: 2.665; b:-1.888 ; k:1.665 & 0.010 & 0.013 & 0.998 \\
\hline 12 & & & CNSL (21) & D380 & Midilli & n: 0.481 ; a: 0.999 ; b: -0.081 ; k: 0.870 & 0.009 & 0.018 & 0.994 \\
\hline
\end{tabular}

Table 2: Parameters of model equations for drying of pellets with formulations based on different raw material, plasticizers at different temperatures. 
temperatures 60,70 and $80^{\circ} \mathrm{C}$ and the parameters for validation of different equations were shown as in Table 2 . The higher value for $\mathrm{R}^{2}$ and the lower values for $\chi^{2}$ and RMSE indicated the better fitness of model Togrul [16], and the best model based on lowest RMSE and $\chi^{2}$ values as well as highest $\mathrm{R}^{2}$ were shown in Table 2 for each formulation.

The results reveal that the best mathematical model for sample A160 is Midilli when $R^{2}$ is 0.999 where the model equation is $M R=a$ $\exp ^{(-k t n)}+b t$ and the parameters are described in Table 2. For different samples, values of $R^{2}$ are obtained in the range of 0.969 to 1.000. Similar type of results was also reported by Augusta et al. [17] wherein they have determined the highest $R^{2}=0.983$ and lowest $\chi^{2}=0.002$ for drying of cork planks. The lowest $\chi^{2}$ values for different samples also determine the best fit of the models as in case of B160, the value of $\chi^{2}$ is 0.004 . For other samples, the range of the $\chi^{2}$ is in between 0.001 to 0.709 . Bassene et al. [13] have reported the similar results of $\chi^{2}$ for drying of millet flour pellets. For all cases, lowest values of RMSE are in between 0.001 to $0.082 \%$.

\section{Effect of temperature variables on drying characteristics}

The results suggested that the Arrhenius law might be applicable to relate the dependence of the rate constant on drying air temperature. The relationship is given by the following equation:

$$
k=k_{o} \exp (-E / R T)
$$

The computed values for activation energy for pellets are shown in Table 3. As evident that the energy required for drying of pellets containing CNSL is more than that of those pellets which contain glycerol as plasticizer. Moreover, it was also seen that the activation energy increased with the increase in the concentration of the CNSL. The dependence of the rate constant on drying air temperatures and types of plasticizers (glycerol and CNSL) are shown in representative graphs as in Figure 2.

\section{Conclusion}

In this study, drying kinetics of pellets were studied at drying air temperatures of 60,70 and $80^{\circ} \mathrm{C}$ using a constant air velocity of $1.5 \mathrm{~m} / \mathrm{s}$. Mathematical modelling allowed the estimation of drying parameters and different models were found fit for different samples of pellets made from different formulations. It was found that drying rate took place in the falling rate period. The drying rate constant was related to

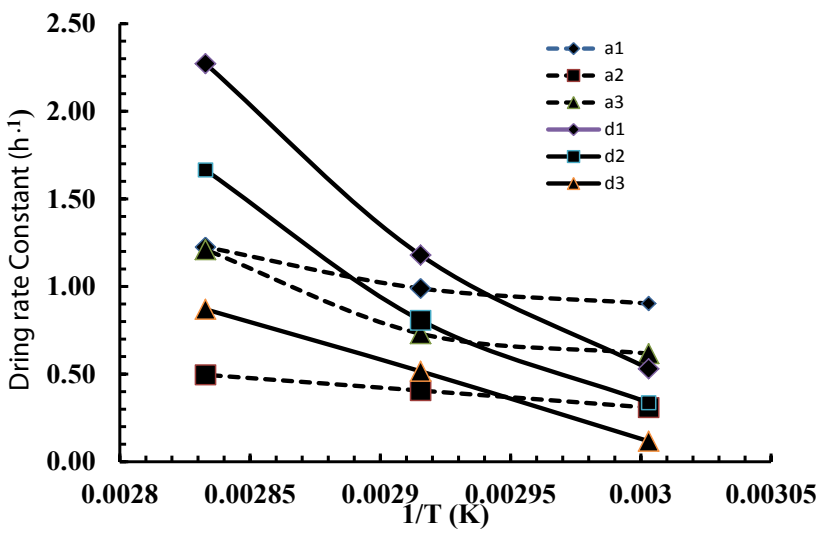

Figure 2: Temperature dependence of the drying rate constant for pellets made from deoiled rice bran $(75 \mathrm{~g})$, paddy husk powder $(75 \mathrm{~g})$ and glycerol $(9,15,21 \mathrm{ml}) /$ CNSL $(9,15,21 \mathrm{ml})$.

\begin{tabular}{|c|c|c|c|c|c|c|c|}
\hline S.No. & \multicolumn{2}{|c|}{ Raw material (g) } & Plasticizer (ml) & Code & $E$ & $\mathbf{k}_{0}$ & $\mathbf{R}^{2}$ \\
\hline 1 & \multirow{6}{*}{ 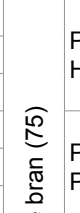 } & \multirow{3}{*}{$\begin{array}{l}\text { Paddy } \\
\text { Husk (75) }\end{array}$} & Gly (9) & A1 & 14.828 & 187.2229 & 0.939 \\
\hline 2 & & & Gly (15) & $\mathrm{A} 2$ & 23.176 & 1347.09 & 0.995 \\
\hline 3 & & & Gly (21) & A3 & 32.732 & 79379.86 & 0.912 \\
\hline 4 & & \multirow{3}{*}{$\begin{array}{l}\text { Potato } \\
\text { Peel (75) }\end{array}$} & CNSL (9) & B1 & 31.21574 & 49266.52 & 0.992 \\
\hline 5 & & & CNSL (15) & B2 & 41.052 & 756153.7 & 0.907 \\
\hline 6 & & & CNSL (21) & B3 & 45.9207 & 4862192.3 & 0.998 \\
\hline 7 & & \multirow{3}{*}{$\begin{array}{l}\text { Banana } \\
\text { Peel (75) }\end{array}$} & CNSL (9) & C1 & 24.6917 & 4577.462 & 0.999 \\
\hline 8 & & & CNSL (15) & $\mathrm{C} 2$ & 26.55741 & 7525.105 & 0.995 \\
\hline 9 & & & CNSL (21) & $\mathrm{C} 3$ & 31.6472 & 145947.2 & 0.951 \\
\hline 10 & & \multirow{3}{*}{$\begin{array}{l}\text { Paddy } \\
\text { Husk (75) }\end{array}$} & CNSL (9) & D1 & 71.02318 & $7.02 \mathrm{E}+10$ & 0.988 \\
\hline 11 & & & CNSL (15) & $\mathrm{D} 2$ & 78.1798 & $4.46 \mathrm{E}+11$ & 0.998 \\
\hline 12 & & & CNSL (21) & D3 & 98.628 & $4.01 \mathrm{E}+14$ & 0.939 \\
\hline
\end{tabular}

aAverage of two values

Table 3: Effect of temperature on drying characteristics ${ }^{\mathrm{a}}$

temperature using the Arrhenius relationship. It would be possible to attain faster drying with increased drying temperature up to $80^{\circ} \mathrm{C}$ with reduced time. It was also seen that the drying energy increased with increasing amount of CNSL in the pellets and the pellets made with glycerol took less energy than that of those made from CNSL.

\section{References}

1. Evans MR, Hensley DL (2004) Plant growth in plastic, peat, and processed poultry feather fiber growing containers. Hort Science 39: 1012-1014.

2. Evans MR, Karcher D (2004) Properties of plastic, peat, and processed poultry feather fiber growing containers. Hort Science 39: 1008-1011.

3. Kowalska E, Wielgosz Z, Pelka J (2002) Use of post-life waste and production waste in thermoplastic polymer compositions. Polymers and Polymer Composites 10: 83-91.

4. Wu Q, Sakabe H, Isobe S (2003) Processing and properties of low cost corn gluten meal/wood fiber composite. Industrial and Engineering Chemistry Research 42: 6765-6773.

5. Yamauchi M, Masuda S, Kihara M (2006) Recycled pots using sweet potato distillation lees. Resources, Conservation and Recycling 47: 183-194.

6. Malinconico M, Immirzi B, Massenti S, Mantia LFP, Mormile P, et al. (2002) Blends of polyvinylalcohol and functionalized polycaprolactone. A study of the melt extrusion and post-cure of films suitable for protected cultivation. Journal of Materials Science 37: 4973-4978.

7. Avella MD, Pace E, Immirzi B, Impallomeni G, Malinconico M, et al. (2007) Addition of glycerol plasticizer to seaweeds derived alginates: influence of microstructure on chemical-physical properties. Carbohydrate Polymers 69: 503-511.

8. Mohanty AK, Misra M, Hinrichsen G (2000) Biofibres, biodegradable polymers and biocomposites: an overview. Macromolecular Materials and Engineering 276-277: 1-24.

9. Manisha J, Srivastava T, Saxena DC (2012) Extrusion processing of deoiled rice bran in the development of biodegradable molded sheets. Scholarly Journal of Agricultural Science 2: 163-178.

10. Akpinar E, Kavak BY (2008) Mathematical modelling of thin layer drying process of long green pepper in solar dryer and tinder open sun. Energy Convers Manage 49: 1367-1375.

11. Togrul IT, Pehlivan D (2004) Modelling of thin layer drying kinetics of some fruits under open sun drying processes, Journal of Food Engineering 63: 349.

12. Felix BD, Julio B, Fernandes (1997) Dilatometry studies of phosphotungstic acid pellets during hydration and dehydration processes and design of a room temperature fuel cell. Journal of Power Sources 74: 1-7.

13. Bassene PT, Gaye S, Talla A, Sambou V, Azilinon D (2013) Experimental and modelling study of thin layer drying kinetics of pellets millet flour. African Journal of Agricultural Research 8: 3806-3813.

14. Singh S, Raina CS, Bawa AS, Saxena DC (2006) Effect of pre-treatments on drying and rehydration kinetics of sweetpotato slices. Drying Technology 24 $1-8$ 
Citation: Jan K, Riar CS, Saxena DC (2014) Mathematical Modelling of Thin Layer Drying Kinetics of Biodegradable Pellets. J Food Process Technol 5: 370. doi:10.4172/2157-7110.1000370

15. Jompob W (2006) A mathematical modelling study of hot air drying for some agricultural products. Thammasat International Journal of Science and Technology 11: 14-20.

16. Togrul $\mathrm{H}$ (2005) Simple modeling of infrared drying of fresh apple slices. Journal of Food Engineering, 71: 311-323.

17. Augusta C, Helena PC (2013) Drying kinetics of cork planks in a cork pile in the field. Food and Bioproducts processing 91: 14-22.

18. O'Callaghan JR, Menzies DJ, Bailey PH (1971) Digital simulation of agricultural dryer performance. Journal of Agricultural Engineering Research 16: 223-244.

19. Doymaz I (2008) Convective drying kinetics of strawberry. Chemical Engineering Process 47: 914-919.

20. Doymaz I (2004) Convective air drying characteristics of thin layer carrots. Journal of Food Engineering 61: 359-364.

21. Ibrahim D (2004) Drying kinetics of white mulberry. Journal of Food Engineering 61: $341-346$

22. Ibrahim M, Sopian K, Daud WRW (2009) Study of the drying kinetics of lemon grass. American Journal of Applied Sciences 6: 1070-1075.
23. Akpinar EK (2006) Determination of suitable thin layer drying curve model for some vegetables and fruits. Journal of Food Engineering 73: 75-84.

24. Balasubramanian S, Sharma R, Gupta RK, Patil RT (2011) Validation of drying models and rehydration characteristics of betel (Piper betel L.) leaves. See comment in PubMed Commons below J Food Sci Technol 48: 685-691.

25. Ertekin C, Yaldiz O (2004) Drying of eggplant and selection of a suitable thin layer drying model. Journal of Food Engineering 63: 349-359.

26. Yaldyz O, Ertekyn C (2001) Thin layer solar drying of some vegetables. Drying Technology 19: 583-597.

27. Midilli A, Kucuk H, Yapar Z (2002) A new model for single-layer drying. Drying Technology 20: 1503-1513.

28. Cihan A, Kahveci K, Hacihafizoglu O (2007) Modelling of intermittent drying of thin layer rough rice. Journal of Food Engineering 79: 293-298.

29. Mohapatra D, Rao PS (2005) A thin layer drying model of parboiled wheat. Journal of Food Engineering 66: 513-518. 